\title{
Linking languages through a bilingual read-aloud project
}

\section{Roy Lyster , Laura Collins \& Susan Ballinger}

To cite this article: Roy Lyster , Laura Collins \& Susan Ballinger (2009) Linking languages through a bilingual read-aloud project, Language Awareness, 18:3-4, 366-383, DOI: 10.1080/09658410903197322

To link to this article: http://dx.doi.org/10.1080/09658410903197322

册 Published online: 15 Oct 2009.

Submit your article to this journal $\pi$

Џlll Article views: 331

Q View related articles $\square$

Citing articles: 15 View citing articles $₫$ 


\title{
Linking languages through a bilingual read-aloud project
}

\author{
Roy Lyster ${ }^{\mathrm{a} *}$, Laura Collins ${ }^{\mathrm{b}}$, and Susan Ballinger ${ }^{\mathrm{a}}$ \\ ${ }^{a}$ Department of Integrated Studies in Education, McGill University, Montreal, Quebec, Canada; \\ ${ }^{b}$ Department of Education, Concordia University, Montreal, Quebec, Canada
}

(Received 25 January 2009; final version received 15 June 2009)

\begin{abstract}
The present study was carried out in French immersion classrooms in an urban Quebec school board that is increasingly characterised by the heterogeneity of its Frenchdominant, English-dominant, and French/English bilingual student population. The study explored the extent to which a bilingual read-aloud project would (1) raise teachers' awareness of the bilingual resources of their students, (2) encourage students' crosslinguistic collaboration, and (3) promote teachers' cross-curricular and cross-linguistic collaboration. The participants were three English and three French teachers of three classes of six- to eight-year-old children. The French and English teachers of each class read aloud to their students from the same storybooks over four months, alternating the reading of one chapter in the French class and another in the English class. The data consist of (1) video recordings of the read-aloud sessions and discussion about the stories, (2) interviews and stimulated-recall sessions with the teachers, and (3) student focus-group interviews as well as a student questionnaire administered at the end of the project. Results are reported in terms of the enthusiasm of both students and teachers for the project, the opportunities it created for teachers and students to focus on both language and content, and the extent to which teachers collaborated to do so.
\end{abstract}

Keywords: bilingual education; awareness-raising; collaboration; literacy practices; second language learning; cross-linguistic contrasts; immersion; reading aloud

\section{Introduction}

Over 40 years ago, an innovation in second language (L2) education began in the Englishmedium schools of St Lambert, a suburb of Montreal (see Lambert \& Tucker, 1972). Anglophone children, a linguistic minority in the province of Quebec, had been receiving instruction in French, the majority language of the province, as a separate subject taught for a few hours a week. The new approach delivered a substantial portion of the academic school day through the medium of French, with the goal of improving the children's mastery of their L2. This subsequently triggered a rapid proliferation of such programmes across Canada, and immersion programmes have since been developed to teach a variety of languages in a wide range of contexts around the world (Johnson \& Swain, 1997).

This educational initiative became the prototypical model for immersion education. A key element of the model is a pedagogical approach that assumes homogeneous first language (L1) groups with similar L2 needs. However, as Swain and Lapkin (2005) have recently noted, (1) immersion students no longer necessarily share the same L1, and (2) the target language can no longer be accurately referred to as the L2 for many students, who increasingly represent culturally diverse and multilingual school populations. At the

\footnotetext{
*Corresponding author. Email: roy.lyster@mcgill.ca 
same time, researchers have begun to question what Cummins (2007) referred to as 'the two solitudes' approach, whereby teachers and students are supposed to speak only French during French instruction time and only English during English instruction time. There is a move towards dropping the prohibition against using students' L1 in the immersion classroom and instead developing practices more in line with findings related to language learners' cognitive use of their L1 in acquiring an L2 (Castellotti \& Moore, 1997; Cook, 2001; Cummins, 1995, 2007; Hawkins, 1984; James, 1996; Swain \& Lapkin, 2005).

These recommendations are relevant to many immersion programmes that have evolved in ways that blur the borders between students' L1 and L2. For example, Basque-medium schools in the Basque Country were originally created as a language maintenance programme for native speakers of Basque, but are now regarded 'as both total immersion programs for native Spanish-speaking students and first language maintenance programs for native Basque speakers' (Cenoz, 1998). Catalan immersion programmes in Catalonia were designed for native speakers of Spanish, but for a school to be designated as an immersion school, as many as $30 \%$ of its students can have Catalan as their family language (Artigal, 1997). In Wales, Baker (1993) writes, 'A Welsh-medium school usually contains a mixture of first language Welsh pupils, relatively fluent second language Welsh speakers, plus those whose out-of-school language is English (i.e., "immersion" pupils)' (p. 15; see Hickey, 2001, for a similar description of Irish-medium education in Ireland). In the United States, 'two-way' immersion programmes integrate a similar number of children from two different mother-tongue backgrounds (e.g. Spanish and English) and provide curricular instruction in both languages (Lindholm-Leary, 2001).

The present study was carried out in French immersion classrooms, specifically in the Montreal area, that comprise an increasingly heterogeneous student population. Currently $38 \%$ of its elementary students claim French as their home language; only 53\% claim English and 9\% claim another language (Hobbs \& Nasso-Maselli, 2005). The overall goal of the study was to explore ways in which French immersion and English language arts teachers could become more aware of the bilingual needs of their learners. More specifically, we set out to investigate how the presence of both English- and French-dominant students in the same classroom - and the linguistic resources that they represent - could be explicitly acknowledged and better exploited and whether it would be possible to foster collaboration between English and French teachers working with the same group of students.

\section{Background}

The recognition that current models of immersion pedagogy do not necessarily address students' diverse linguistic needs (including the potential for students to act as linguistic resources for each other) needs to be seen as part of an overall concern for more effective integration of a focus on language in content-based instruction. In this section, we briefly trace the origins for the current concern, to contextualise the issues explored in the present study.

The first 'early immersion' programme in St Lambert was based on the premise that young children are naturally predisposed to learn an additional language through early exposure in message-oriented contexts. In their seminal evaluation of this educational innovation, Lambert and Tucker (1972) reported positive results with respect to the children's language development in both English and French, as well as their academic achievement and affective development. The programme's success has been attributed to its seemingly seamless integration of cognitive development and language development. As Snow, Met, and Genesee (1989) argued, language development and cognitive development go hand 
in hand for young children, yet more traditional methods tend to separate language development from general cognitive development, isolating the target language from any substantive content except for the mechanical workings of the language itself. Immersion education, in contrast, is designed to integrate language and cognitive development.

One of the most widely substantiated outcomes of immersion programmes is that students' L1 development and academic achievement are similar to (or better than) those of non-immersion students (Genesee, 1987, 2004; Swain \& Lapkin, 1982; Turnbull, Lapkin, \& Hart, 2001). Another finding common across immersion programmes is that students develop much higher levels of L2 proficiency than do non-immersion students studying the L2 as a subject for about 40 minutes each day. At the same time, research on the L2 proficiency of French immersion students in Canada has long suggested that even higher levels of proficiency approximating native-speaker norms of grammatical and sociolinguistic competencies might be attainable through improved instructional strategies (Allen, Swain, Harley, \& Cummins, 1990; Harley, 1993; Harley, Cummins, Swain, \& Allen, 1990; Swain, 1988, 1996). Lyster (2007) pointed out that instructional practices designed to foster continued L2 growth through immersion were initially formulated rather tentatively and thus underlie the attested shortcomings that characterise students' L2 proficiency. Immersion pedagogy drew on input-based communicative language teaching theories that emphasised content goals over language goals and avoided explicit attention to language, whereas researchers working across a range of content-based contexts now argue that language learning goals should become more prominent and explicit (e.g. Swain \& Lapkin, 2002: French immersion classrooms in Canada; Fortune, Tedick, \& Walker, 2008: Spanish immersion classrooms in the United States; Dalton-Puffer, 2007: content and language integrated learning [CLIL] classrooms in Europe). Two related concerns are the need to recognise the linguistic and cultural diversity in the immersion classroom (Cummins, 1995, 2007; Duff, 2007; Swain \& Lapkin, 2005), as mentioned above, and the potential advantages of engaging learners' cognitive resources through explicit attention to L1-L2 comparisons (Cummins, 2007; Hawkins, 1999; James, 1996; Swain \& Lapkin, 2005; White, Horst, \& Bell, 2008).

\section{Research goals and design}

Our two-year study was exploratory in nature, benefitting from funding provided by the Social Sciences and Humanities Research Council of Canada to support 'research development initiatives' involving experimentation in the early stages of the research process. The first year of our study was devoted to preliminary classroom observations, while the second year involved the implementation of the bilingual read-aloud project, which is the main focus of this paper.

\section{Year 1: preliminary classroom observations}

During the first year we observed seven groups of students in four different schools from kindergarten to grade 6 . Our aim was to explore the ways in which teachers and students were already responding to the language situation in their classrooms. In our field notes, we focused on language use by teachers and students in both the French immersion content classes and English language arts classes and the instances of cross-linguistic and crosscurricular collaboration among the French and English teachers of the same students. A further objective was to identify pairs of teachers (French and English) working with the same students who would be willing to participate in a collaborative research project. 
Our observations during year 1 revealed that in all classes at all grade levels, the languages of the children were kept separate. In addition, children who were dominant in one language were rarely encouraged to help their less proficient peers when the class was being conducted in their strong language or to seek assistance from a more proficient peer when the language of instruction changed to their less dominant language. Cross-linguistic references were rare on the part of the teacher, although the children themselves would occasionally refer to their developing knowledge of the two languages. For example, during a vocabulary-building activity in the English language arts class in grade 5 (10- to 11-yearolds), an English-dominant child whose French language skills were among the weakest in her class nonetheless observed that the word 'crescent' in 'crescent moon' reminded her of 'croissant' in French. We did not observe any systematic collaboration between French and English teachers at any grade level. However, all teachers were concerned enough about the heterogeneity of their groups to welcome us into their classes in anticipation of some guidance on how to better address the needs of the children.

\section{Year 2: the bilingual read-aloud project}

At the end of the preliminary observations conducted during year 1, we identified three pairs of English and French teachers (grades 1-3) who were interested in working with us and each other and who taught classes with similar proportions of English-dominant and French-dominant students. In consultation with these six teachers, we proposed a bilingual read-aloud project to assess whether it was a feasible means for French and English teachers to collaborate in a way that would facilitate cross-linguistic connections. Teachers reading aloud to their students had been a common activity we observed at all age levels in both English and French classes during preliminary observations in year 1, and was thus considered sufficiently congruent with these teachers' instructional styles to facilitate collaboration among teachers and with our research team. The bilingual twist to the project, implemented during year 2, was that the French and English teachers of each class read aloud to their students from the same storybooks over four months, alternating the reading of one (or more) chapter(s) in the French class with another in the English class. The goals of the project were (1) to raise teachers' awareness of the bilingual resources of their students, (2) to encourage students' cross-linguistic collaboration, and (3) to promote teachers' cross-curricular and cross-linguistic collaboration.

\section{Participants}

Three early French immersion classes and three pairs of teachers participated in the bilingual read-aloud project. Each teacher pair consisted of the homeroom French teacher (who had the children most of the day) and the English language arts teacher (who, depending on the school, taught the children from three to five hours per week). There was one grade 3 class, one split class that included both grade 1 and grade 2 students, and one grade 2 class. Each immersion class was in a different school within the same school board.

The grade 3 class consisted of 24 students: 8 English-dominant, 8 French-dominant, and 8 French/English bilinguals. ${ }^{1}$ The French teacher was a francophone with minimal knowledge of English. She had taught at the school for seven years. She had a bachelor of education degree from a French-speaking university, with a focus on special-needs students, but no specific teacher training in L2 teaching. The English teacher was bilingual in English and Greek and had some knowledge of French. She had completed a one-year teaching programme prior to becoming an elementary school teacher and, like her counterpart, had 
no specific training in L2 teaching. She had taught grades 3 and 4 at the school for 22 years and had begun teaching English language arts in the French immersion stream 10 years earlier.

The grade 1/2 class consisted of 20 students: 10 English-dominant and 10 Frenchdominant. The French teacher was a francophone with minimal knowledge of English, who had been teaching at the school for seven years. The English teacher was fluently bilingual in French and English and had been teaching grade 2 at the same school for six years. Both had completed bachelor of education programmes, but neither had received specific training in L2 pedagogy.

The grade 2 class consisted of 24 students: 5 French-dominant, 11 English-dominant, 5 English/French bilingual, and 3 Chinese-dominant with varying abilities in English and French. The French teacher was a francophone who was fluently bilingual in English and French and had taught at the school for eight years. She had both a bachelor of education degree and a teaching English as second language (TESL) certificate. The English teacher was an anglophone with strong communicative skills in French, who had been a French immersion student herself. She was in her first year of teaching and had completed a bachelor of education degree the previous year, but she had no L2 teacher training. ${ }^{2}$

\section{The books}

The three chapter books were selected in consultation with all six teachers. The books were written by Mary Pope Osborne, published in English in the Magic Tree House series by Random House (Osborne, 1998a, 1998b, 1998c) and in French in the Cabane Magique series by Bayard Jeunesse (Osborne, 2003a, 2003b, 2003c). The theme across all three stories was 'books' and how writing changes across time and space. The main characters in each story were the same two children who were given a mission in each story to travel back in time in a magic tree house to recover books in danger of being lost or destroyed.

Book 1. In Vacation under the Volcano/Panique à Pompéi, the characters travel back to $79 \mathrm{AD}$ to retrieve the legend of Hercules. In Roman times, the readers are informed, books were scrolls made of papyrus and written in Latin with pens made of reeds and octopus ink.

Book 2. In Day of the Dragon King/Le terrible empereur de Chine, the duo is sent to ancient China to retrieve the Chinese legend of the silk weaver and the cowherd. Readers become aware that in ancient China, before the invention of paper, books were made of bamboo strips displaying Chinese calligraphy.

Book 3. In Viking Ships at Sunrise/L'attaque des Vikings, the characters travel to Ireland to retrieve an ancient Irish tale about a sea serpent. Readers learn that in Ireland during the Middle Ages, books were handwritten in Latin and decorated by monks in monasteries using sheepskin and pens made of goose quills.

\section{Procedure and data collection}

The primary source of data in the study is a total of 26.8 hours of video recordings of the read-aloud sessions in the three classrooms. During the video recordings, two researchers were present, one operating the camera and the other taking field notes. The video recordings 
capture not only the teacher reading the story aloud but also considerable teacher-student and peer interaction about the stories.

Other data sources include teacher interviews and stimulated-recall sessions. All teachers were individually interviewed regarding their teaching and language learning histories, their opinions related to teaching both English- and French-dominant children, and their response to the bilingual readings. Two stimulated-recall sessions with the teachers took place, one after the reading of the first book and the other after the reading of the third book. In both sessions, teachers were interviewed as they watched and discussed video recordings of their readings. The first session was conducted with all six teachers together and served primarily as a feedback and preparation session for the readings of the following two books. The second session was done with each pair of teachers separately. The excerpts chosen for the viewings focused on (1) instances where teachers or students made cross-linguistic references, (2) samples of the same students' participation in the French and English readings, and (3) treatment of the same vocabulary item/concept in the two languages. At the final stimulated-recall session teachers were also asked a set of questions related to the research objectives of the project. (The interview protocol which guided the stimulated-recall sessions and general discussion appears in Appendix 1.) These stimulatedrecall sessions (total of 5 hours and 45 minutes) were audio-taped and transcribed for analysis.

After the reading of the first book, data from students were collected through focusgroup interviews with two subsamples of children from each of the three classes. For each class, a French-dominant group and an English-dominant group of students were interviewed in their respective language of dominance, and these interviews were also video-recorded, totalling 2 hours and 14 minutes of student interview data. Finally, at the conclusion of the bilingual reading project, a questionnaire was administered to all children for the purpose of collecting biodata on their language dominance and language use at home, as well as their reactions to the project. The questionnaire was administered in French; an English translation appears in Appendix 2.

Collaboration with the six teachers began in June 2007 when they attended an initial planning meeting. Over the summer, we consulted with the teachers to select the books. A pre-reading preparation meeting was then held in October 2007 during which we introduced the procedure to teachers, brainstormed about collaborative ideas, gave teachers time to plan, and provided the following instructions: prior to each reading, teachers were to have their students summarise the content of the previous reading (which had taken place in the other language of instruction), and after each reading they were to have their students make predictions about the next chapter. We had observed some teachers making use of such strategies during the monolingual reading-aloud sessions during Year 1. This design was implemented for the bilingual read-aloud sessions to establish a common procedure and to offer both teachers and students opportunities for making cross-linguistic connections between the bilingual readings. Teachers were not required to implement supplemental activities related to the books, but all three pairs of teachers used the initial planning time they were given to brainstorm about the kinds of follow-up activities that could be done.

The reading aloud of Book 1 began in November 2007 and continued through to January 2008. The first debriefing meeting was then held in early February 2008. It was conducted as a stimulated-recall session with all six teachers. The reading of Book 2 began immediately after this session and continued until the spring break in March, after which Book 3 was begun and finished in early May. During May 2008, stimulated-recall sessions were held in separate sessions with each pair of teachers. 


\section{Results}

Before reporting the findings directly related to the research objectives we had at the outset (raising teachers' awareness of the students' bilingual resources and encouraging cross-linguistic and cross-curricular collaboration), we will begin with the students' and teachers' overall response to the bilingual read-aloud project. We will then address the research questions in three separate sections dealing with connections that were made across the French and English classes in terms of (1) content, (2) language, and (3) teacher collaboration.

\section{Participants' attitudes}

The video recordings and field notes revealed that students responded positively to the bilingual reading project through their active, attentive, and enthusiastic participation in the sessions. In the student rankings of the three books, as elicited by the final questionnaire, $93 \%$ of the grade 3 rankings, $66 \%$ of the grade 2 rankings, and $83 \%$ of the grade $1 / 2$ rankings were in the top category of ' $J$ 'ai BEAUCOUP aimé ce livre'. Moreover, 22 of the 23 participating grade 3 students and 14 of the 23 participating grade 2 students stated that they had continued to read other books in the Magic Tree House series on their own. (The grade 1/2 split did not have sufficient literacy skills to do so.) During focus-group interviews, students were asked whether they liked the books, and if so, which part of the story they liked the most. Invariably, they gave a resounding yes to whether they liked the Magic Tree House books, and several students stated that they could not choose a favourite part because they liked the whole story. When focus-group students from the grade $1 / 2$ class were asked how they could remember whether a certain part of the story had been read aloud in French or in English, one answered, 'Ben moi c'est parce que je l'ai aimé beaucoup puis pour des affaires que j'aime beaucoup, je les garde toujours dans ma tête puis dans mon cœur [Well for me, it's because I liked it a lot and for things that I like a lot, I keep them forever in my head and in my heart].'

Most of the focus-group students did not voice preferences or concerns regarding the experience of having the story read aloud to them in two languages. When pressed, a few students stated that they found it confusing or strange to be read to bilingually, while others said that it was helpful for students who were having difficulty in one of the two languages. For example, one English-dominant, grade 3 student explained, ' 'Cause in French you could at least understand what's going to happen, but in English you would know what happened in French.'

The teachers concurred that the high level of student interest was partly due to the bilingual reading that helped reach all students, regardless of language dominance, to understand the stories. For example, the grade 3 English teacher stated, '[Those students] who don't have a big vocabulary in English, I think it helped them come into the story when I was reading the English version because they had a little idea of what was happening.'

Similarly, again as evidenced during video-taped read-aloud sessions, as well as in teacher interviews and the stimulated-recall sessions, the teachers also responded positively and enthusiastically. The grade 1 and grade 2 teachers all noted that although they had been sceptical at first of their students' ability to participate in such a project, they were pleasantly surprised by the results. The grade 1 French teacher reported, 'J'ai trouvé que le vocabulaire était assez, peut-être, difficile. Mais j'ai changé d'avis quand j'ai vu les enfants embarquer là-dedans et puis s'intéresser. [I found the vocabulary quite, maybe, difficult. But I changed my mind when I saw the students get involved and then interested.]' The grade 2 English teacher commented in a similar vein, 'We were really concerned that there weren't enough 
pictures and, you know, how are they going to follow the story and on top of it, we're going from English to French. But they really did not have a problem with it. They really didn't.'

A final proof of the projects' popularity was that the two schools that did not already have the entire Magic Tree House series ordered the collection for their libraries.

\section{Focus on content}

The stories provided content that was addressed across the students' curriculum in both French and English. The stories lent themselves well to typical content teaching in the sense that Pompeii, ancient China, and the Vikings were motivating themes with educational value. For example, Book 1 allowed students to learn about ancient Roman villages and the story of Pompeii and its infamous volcano, which teachers related to the study of natural disasters. Book 2 about ancient China allowed teachers to focus on content related to silk production as well as well-known landmarks such as the Great Wall and the Terracotta Army in the country about to host the 2008 Olympic Games. Book 3 focused on Viking invasions and related seafaring notions, as well as on medieval monasteries and the role monks played in book-making.

Students were thus often learning a new concept along with two new words. For example, during the reading of Book 1, sundials were a new concept to which students were exposed in both languages (cadran solaire/sundial). During Book 2, students learned about silk and soie, while Book 3 introduced them to monasteries and monastères, to invaders and envahisseurs. Whereas two new words for a new concept might be considered an additional learning challenge for the students, in response to this interview question (see no. 8 in Appendix 1), all three pairs of teachers believed that this helped reinforce the concept for the children, a point to which we return below.

While the themes of these books created cross-curricular opportunities for reinforcing new concepts in both the English and French classes, the students' interest in the narratives seemed to take precedence over their attention to the language in which it was read. For example, when asked to recount their favourite part of Vacation under the Volcano, most focus-group students were keen to respond but had difficulty remembering which language it had been read in, as illustrated by the following exchange between students (Ss) from the grade $1 / 2$ class and the researcher $(\mathrm{R})$ :

\section{Extract 1}

S1: I think it was French.

S2: No, it was English.

S4: It was English.

R: And what about you two? What was your favourite part?

S4: No. It was French.

S2: It was English

S4: No. French.

S2: English.

R: So there's some disagreement about whether it was English or French. That's OK. I want to hear about your favourite parts.

\section{Focus on language}

In this section, we focus on teachers' awareness of their students' bilingual resources and needs and on the nature of the cross-linguistic references observed in both students' and teachers' discourse. 
In her seminal research on immersion classrooms, Swain (1985, 1988; see also Allen et al., 1990) reported that typical content teaching does not necessarily create sufficient opportunities for extensive language production on the part of students or for feedback on language provided by teachers. One of the most striking findings in the present study was the observation that the story retellings and predictions indeed created extensive opportunities for student production along with peer and teacher feedback, as well as opportunities for student-initiated discourse.

\section{Extract 2}

S1: I have something to add to that, when they fire the books.

T: Go ahead

S1: When they fire the books uh...

T: When they what?

S1: When they fire the books

T: What do they mean when they 'fire the books?'

Ss: ...

T: No let her say it in another way, explain it to me in another way. When they put fire on the books. What's that when we put fire to make a fire? What do we do? We put things in the fire we say we...

Ss: Burn things.

T: Burn things. Good, continue.

S1: When they burnt it the guy just burn the book that he didn't write, he kept the books that he write, he wrote.

In this extract, the student herself initiates the exchange ('I have something to add to that') and then her non-target output ('fire the books') results in negotiation of form between teacher ( $\mathrm{T}$ ) and students. Her peers propose the correct form ('burn'), which the student then incorporates into the comment she was trying to make.

In the grade 3 English class, the teacher often made many cross-linguistic references through requests for translation equivalents; she also encouraged students to respond in French if they were unable to formulate their answers in English.

\section{Extract 3}

T: What does that mean, Donald, little helmets? What does that mean?

S1: I don't know.

T: Well, you see the little helmets that are on their heads on the cover? How do we say it in French?

S2: Les petits casques.

T: Shhh. Donald, how do we say that in French?

S1: Les petits casques...

T: Casques. Do we wear helmets today?

Interestingly, the English teacher's reiteration for this L2 speaker of English that helmets are casques in French seemed to have had a positive effect in the French class days later as students retold the chapter in French.

\section{Extract 4}

S: Ils s'en allaient quelque part quand le bateau ... y ont trouvé des ... Annie a trouvé des ... elle a trouvé des casques... des Vikings.

[They were going somewhere when the boat ... they found some ... Annie found some ... she found some helmets ... of Vikings]

T: Oh! Bonne mémoire! [Oh! Good memory!] 
In the English portion of the grade 1/2 class, French-dominant children were encouraged to participate in the retellings and chapter summaries by rendering their idea in French, which was then recast by the teacher in English and repeated by the child (and sometimes chorally by the whole class).

\section{Extract 5}

T: There's something else that happens ... raise your hand. Yes.

S2: Um ... Est-ce que je peux en français? Um, la cabane magique, elle tourne. [Can I in French? Um, the magic tree house, it spins.]

T: It, it spins around. Yeah, so say that: the tree house spins around.

S2: The tree house spins around.

Not only did this approach help bridge the gap between L1 and L2 for particular children, it sometimes served to reinforce a concept for all children. In the extract below, all of the students (including the English-dominant students) needed some guidance to grasp that monasteries were places where monks worked. However, one of the French-dominant students had understood this notion and rendered it in her L1, which was subsequently recast by the teacher in English and repeated by the original student and then by the whole group.

\section{Extract 6}

T: Who lives in this monastery? Yes?

S1: Um, can I say in French? Est-ce que c'est des monastères? [Is it monasteries?]

T: Yes, that's good. That's in French. And who lives there? In that one? [showing picture]

S1: C'est des moines qui, qui travaillent. [It's monks who, who work.]

T: OK, so you say it in English now. The monks, wait a minute, the monks live in the monastery.

S1: The monks live in the [hesitation] monastery.

T: [helping] Monastery. Let's all say it.

Ss: The monks live in the monastery.

Such cross-linguistic references were rare in the French classes, where students' attention was drawn to vocabulary mainly to explain new or difficult words in French (see Allen et al., 1990) rather than to highlight L1-L2 contrasts. Two of the French teachers lacked sufficient knowledge of English to make L1-L2 comparisons, and so, instead of asking for English equivalents in French, tended to request synonyms and explanations for French words in French, as in the following exchange in the grade 3 class about the meaning of brouillard (fog).

\section{Extract 7}

T: Qu'est-ce que ça veut dire, le 'brouillard'? Tu as une idée, Justin?

[What does 'brouillard' mean? Do you have any idea, Justin?]

S1: C'est comme, je sais pas comment dire en français. C'est fog.

[It's like, I don't know how to say it in French. It's fog.]

T: Je suis pas bonne avec mon anglais. Est-ce que c'est la bonne traduction? On va aller avec un mot français...

[I'm not good with my English. Is that the right translation? Let's go with a French word.]

S2: C'est comme, quand tu rentres dans du brouillard, c'est comme du gaz qui se promène partout.

[It's like, when you go into fog, it's like gas that's going all over the place.]

T: Oh là là! Mmm ... 
S3: C'est pas comme du gaz mais c'est comme de la fumée ...

[It's not like gas, but it's like smoke ... ]

The grade 3 French teacher also made frequent references to word families, as in the following examples.

\section{Extract 8}

T: Qu'est-ce que c'est qu'une bibliothèque impériale? Pensez au mot impériale, du mot ...

[What's an imperial library? Think of the word imperial, from the word ... ]

S: Empereur... [Emperor...]

\section{Extract 9}

T: Cadran solaire, le mot solaire fait penser à quel mot?

[Sundial, the word solar makes you think of what word?]

Ss: Soleil. [Sun.]

Interestingly, given the aforementioned bilingual focus of the English teacher, the latter succeeded in reinforcing the solaire-soleil connection in explaining sundial two days later in English.

\section{Extract 10}

T: A sundial ... Un cadran solaire. Cadran ... what's that in English?

S: Clock.

T: And what's solaire?

S: Sun.

T: So, sundial ...

In response to interview question no. 7 (see Appendix 1), which focused on the insights into their students' abilities/needs that the bilingual reading may have provided, all three pairs of teachers reported that it was the video viewing with the researchers that provided the most valuable information, as this activity gave them the opportunity to observe different children speaking in their other language. Teachers also mentioned that they would occasionally consult with each other on how students who were much more dominant in one language were handling the reading in their less dominant language. Although these exchanges were brief and did not lead to jointly elaborated strategies for supporting these children's needs, they nevertheless represented a much more regular consultation between the two pairs of teachers than would normally have taken place. This raises the issue of the nature of the collaboration that resulted from the bilingual read-aloud project, to which we now turn.

\section{Teacher collaboration}

Some of the exchanges presented in the foregoing sections illustrated cross-curricular and cross-linguistic connections, especially in the case of new concepts being reinforced by both teachers in both languages. However, we found that all of these cross-linguistic connections occurred incidentally rather than resulting from collaborative planning. This was confirmed by the stimulated-recall sessions as each pair of teachers commented on selected video recordings. They reported that they did not collaborate on language teaching objectives and did not see the project as being particularly different from regular classroom activities in terms of language objectives. There was some sharing of material within the grade 3 and grade $1 / 2$ pairs of teachers, but this consisted primarily of one teacher giving 
another some resources or follow-up ideas related to the theme of the book, which was then pursued by each teacher individually. The grade $1 / 2$ French teacher explained the casual nature of her and her colleague's collaboration: 'On arrive toujours de bonne heure puis quand on a un petit cinq minutes on se parle, puis on s'arrange comme ça [We always arrive early and when have five minutes to spare we talk and we manage like that].' At the teachers' request, we supplied Duotang folders for each student into which students could insert any of the paper-based tasks they did in either the French or the English class. None of these tasks had resulted from, or led to, collaboration between teachers. In fact, one of the pairs of teachers discovered during the final debriefing session that they had both focused on a similar writing objective for compositions (transition words) without either knowing it.

Teachers agreed that time was lacking in their day for systematic collaboration. Commenting on this, the grade 3 French teacher said, 'On fait les projets puis on apporte nos choses dans nos sacs mais on travaille seule le soir à la maison parce qu il n'y a pas de temps, et souvent quand il y a des journées pédagogiques, bien, on a la formation à la commission scolaire ... [We do projects and we bring things home to work on alone in the evening because there's no time, and often when there are professional development days, well, we have training at the school board].' Similarly, the grade 3 English teacher stated, 'I see [my colleague] at 4 p.m. and she's still at her desk working, I'm not going to disturb her ... . We're teachers in the same building and we never have a chance to talk to one another. Yes, it took you guys to bring us together to discuss and, you know, re-energize us or just like spark our imagination.'

The teachers acknowledged during the follow-up interviews that they could have and would have liked to have done more, such as collaborating to at least identify a vocabulary list of key words that was important for understanding the content of the chapters. When asked what they would recommend other teachers do if they were implementing the same project, the grade 2 English teacher replied, 'Find time together. Find time to get together,' to which her colleague added, 'Actually sit down and that's one thing we didn't do.'

As a result, in addition to the connections presented in preceding sections to illustrate the pedagogical possibilities inherent in a bilingual read-aloud project such as ours, we observed many disconnections owing to a lack of more collaborative planning and resulting in missed teachable moments. Many such disconnections pertained to the content of the stories. For instance, in one chapter, the grade 3 students learned that Mt Vesuvius notably rained pumice, not lava, on the residents of Pompeii. In her follow-up activity to this chapter, their English teacher led a lengthy discussion on pumice and then re-enacted a scene from the chapter by tying pillows to her students' heads and then gently hitting the pillows with a pumice stone to illustrate how some residents of Pompeii survived the eruption. However, in the following class, the French teacher demonstrated that she was unaware of her colleague's pumice-related activities; when the students were summarising the events of the previous chapter, she repeatedly tried to elicit that lava poured from Mt Vesuvius until their protests became so strong that she abandoned the topic.

Other 'disconnections' resulted from minor differences between the French and English versions of the stories. One such difference was that in the French version the characters come from a small town in France, while in the English version they come from Pennsylvania. The following exchange occurred in the grade 2 English class.

\section{Extract 11}

S1: But in the French book, they come from France. Don't they?

S2: Yeah.

T: It's very possible. I believe it ... 
Here we see that students initiated their own questions about the stories, but because the teachers tended to focus on the content of the story in the language version they were reading, there were missed opportunities for discussing the differences, such as why the publishers might have given the English- and French-speaking characters different hometowns.

\section{Conclusion}

One of the most interesting results of this exploratory study was the high level of motivation that it generated among students, as observed in their interest in being read the stories aloud in both languages as well as volunteering to retell previous happenings and predict upcoming events. Moreover, their interest in continuing to read similar stories on their own was striking. The high level of student motivation was likely due in part to the exciting and educational stories in the Magic Tree House series, and also to the bilingual reading itself that allowed all students, irrespective of language dominance, to understand the stories and engage with the content. Although a possible observer effect may have been at play, whereby the video-taping of the read-aloud sessions served to motivate students to participate enthusiastically, such an effect does not explain the students' enthusiasm for continuing to read these books on their own.

This project created opportunities for collaboration among teachers who had not previously collaborated, and the teachers clearly appreciated this aspect of the project as demonstrated in the grade 3 French teacher's statement, 'On se sentait pas tout seul dans le projet [We didn't feel all alone in the project],' and in the grade 1/2 teachers' discussion given below.

\section{Extract 12}

English teacher: Moi, je trouve ça 'fun'. [I find it fun.]

Researcher: De se consulter? [To consult one another?]

Both teachers: Oui. [Yes.]

Researcher: Et comment est-ce que vous avez organisé ça?

[And how did you organize that?]

French teacher: On a travaillé en équipe. [laughter and chatter]

[We worked as a team.]

Researcher: Est-ce que vous avez travaillé en équipe avant ça?

[Have you ever worked as a team before?]

English teacher: Non ... [No ... ]

The collaboration consisted primarily of brief conversations about individual students, the students' reaction to the stories, and some (but not all) of the follow-up activities each teacher was conducting on her own with the group.

Actual collaboration on either content- or language-based objectives, however, was minimal. There was no collaboration on common activities, exploiting the various curricular themes that emerged from stories; nor was there any collaboration driven specifically by language learning objectives. This may reflect the teachers' priorities as shaped by their educational background, which did not include any specific training in L2 teaching. Similarly, it may reflect the general nature of content-based programmes, which are known to approach language teaching objectives in primarily incidental ways. In addition, there may be an overriding culture of non-collaboration in these schools, influenced to a large extent by a lack of time built into the school day for such collaboration, exacerbated by the pressure teachers are under to cover large amounts of curriculum material while responding to a wide range of individual learners' needs. 
The bilingual read-aloud project as outlined here is a relatively easy-to-implement activity that proved successful in initiating cross-linguistic collaboration. However, to better exploit the potential that such a project has to enhance L2 learning, more intervention and guidance would be needed. Future interventions could include a more intentional focus on key lexical items and word families both within and across languages. This preparation would perhaps also encourage teachers who do not necessarily have strong language skills in both of the children's developing languages (which, in our project, was the case for two of the three French teachers) to feel more at ease with cross-linguistic references. Thematic projects and writing projects that require students to use both their languages could be undertaken. For example, one of the French teachers was having the students invent their own Magic Tree House adventure for the two protagonists, following the familiar structure (and vocabulary) that was used in the books. This would appear to be an ideal activity for collaboration among students with different language dominances, in which sections of the story could alternate back and forth between languages. Future research deriving from this project will focus on such activities and on developing strategies for students to more effectively and efficiently serve as linguistic resources during peer collaboration as they develop their bilingual proficiency together.

\section{Acknowledgements}

The bilingual read-aloud project received financial support from the Social Sciences and Humanities Research Council of Canada (grant 820-2005-1015). We gratefully acknowledge the generous cooperation of the participating principals, teachers, and students. We would also like to recognise the following research assistants who contributed to various phases of this study: Juan Abrile, Gabrielle Beaudoin, Jacqueline Landry, Myra Lepp, Alicia Piechowiak, Masatoshi Sato, Jimena Terraza, Cathy Thibault, Dina Tsoulos, and Mélanie Walkty. Parts of this study were presented in June 2008 at the annual meetings of the Canadian Association of Applied Linguistics in Vancouver and the Association of Language Awareness in Hong Kong, as well as in October 2008 at the 'Pathways to Bilingualism and Beyond' conference in St Paul, MN.

\section{Notes}

1. The language dominance of the children was initially identified by the teachers and then verified during the classroom observations and student questionnaires administered at the end of the study.

2. In Quebec it is common for French immersion teachers to have completed a general bachelor of education degree focused on the French mother tongue, with little or no training in L2 pedagogy. Similarly, because the model of immersion 'assumes' homogeneous groups of anglophone children, the English language arts teachers have usually been trained in English mother tongue pedagogy.

\section{Notes on contributors}

Roy Lyster is Professor of L2 education in the Department of Integrated Studies in Education at McGill University in Montreal.

Laura Collins is Associate Professor of applied linguistics in the Education Department at Concordia University, Montreal, and the L2 theme leader at the Centre for the Study of Learning and Performance at Concordia.

Susan Ballinger is a PhD candidate in the Department of Integrated Studies in Education at McGill University in Montreal. 


\section{References}

Allen, P., Swain, M., Harley, B., \& Cummins J. (1990). Aspects of classroom treatment: Toward a more comprehensive view of second language education. In B. Harley, P. Allen, J. Cummins, \& M. Swain (Eds.), The development of second language proficiency (pp. 57-81). Cambridge: Cambridge University Press.

Artigal, J. (1997). The Catalan immersion program. In K. Johnson \& M. Swain (Eds.), Immersion education: International perspectives (pp. 133-150). Cambridge: Cambridge University Press.

Baker, C. (1993). Bilingual education in Wales. In H. Baetens Beardsmore (Ed.), European models of bilingual education (pp. 7-29). Clevedon: Multilingual Matters.

Castellotti, V., \& Moore, D. (1997). Alterner pour apprendre, alterner pour enseigner, de nouveaux enjeux pour la classe de langue. Études de Linguistique Appliquée, 108, 389-392.

Cenoz, J. (1998). Multilingual education in the Basque Country. In J. Cenoz \& F. Genesee (Eds.), Beyond bilingualism: Multilingualism and multilingual education (pp. 175-191). Clevedon: Multilingual Matters.

Cook, V. (2001). Using the first language in the classroom. The Canadian Modern Language Review, $57,402-423$.

Cummins, J. (1995). The European schools model in relation to French immersion programs in Canada. In T. Skutnabb-Kangas (Ed.), Multilingualism for all (pp. 159-168). Lisse, The Netherlands: Swetz \& Zeitlinger, B.V.

Cummins, J. (2007). Rethinking monolingual instructional strategies in multilingual classrooms. Canadian Journal of Applied Linguistics, 10, 221-241.

Dalton-Puffer, C. (2007). Discourse in content and language learning (CLIL) classrooms. Amsterdam: John Benjamins.

Duff, P. (2007). Multilingualism in Canadian schools: Myths, realities and possibilities. Canadian Journal of Applied Linguistics, 10, 149-164.

Fortune, T., Tedick, D., \& Walker, C. (2008). Integrated language and content teaching: Insights from the immersion classroom. In T. Fortune \& D. Tedick (Eds.), Pathways to multilingualism: Evolving perspectives on immersion education. Clevedon: Multilingual Matters.

Genesee, F. (1987). Learning through two languages: Studies of immersion and bilingual children. Cambridge, MA: Newbury House.

Genesee, F. (2004). What do we know about bilingual education for majority language students? In T. K. Bhatia \& W. Ritchie (Eds.), Handbook of bilingualism and multiculturalism (pp. 547-576). Malden, MA: Blackwell.

Harley, B. (1993). Instructional strategies and SLA in early French immersion. Studies in Second Language Acquisition, 15, 245-259.

Harley, B., Cummins, J., Swain, M., \& Allen, P. (1990). The nature of language proficiency. In B. Harley, P. Allen, J. Cummins, \& M. Swain (Eds.), The development of second language proficiency (pp. 7-25). Cambridge: Cambridge University Press.

Hawkins, E. (1984). Awareness of language: An introduction. Cambridge: Cambridge University Press.

Hawkins, E. (1999). Foreign language study and language awareness. Language Awareness, 8, 124 142.

Hickey, T. (2001). Mixing beginners and native speakers in minority language immersion: Who is immersing whom? The Canadian Modern Language Review, 57, 443-474.

Hobbs, J., \& Nasso-Maselli, M. (2005). Elementary programs study. St Lambert, QC, Canada: Riverside School Board.

James, C. (1996). A cross-linguistic approach to language awareness. Language Awareness, 5, 138 148.

Johnson, K., \& Swain, M. (1997). Immersion education: International perspectives. Cambridge: Cambridge University Press.

Lambert, W., \& Tucker, R. (1972). Bilingual education of children: The St. Lambert experiment. Rowley, MA: Newbury House.

Lindholm-Leary, K. (2001). Dual language education. Clevedon: Multilingual Matters.

Lyster, R. (2007). Learning and teaching languages through content. Amsterdam: John Benjamins.

Osborne, M. (1998a). Day of the Dragon King. New York: Random House.

Osborne, M. (1998b). Vacation under the volcano. New York: Random House.

Osborne, M. (1998c). Viking ships at sunrise. New York: Random House.

Osborne, M. (2003a). L'attaque des Vikings. Paris: Bayard Jeunesse. 
Osborne, M. (2003b). Le terrible empereur de Chine. Paris: Bayard Jeunesse.

Osborne, M. (2003c). Panique à Pompéi. Paris: Bayard Jeunesse.

Snow, M., Met, M., \& Genesee, F. (1989). A conceptual framework for the integration of language and content in second/foreign language instruction. TESOL Quarterly, 23, 201217.

Swain, M. (1985). Communicative competence: Some roles of comprehensible input and comprehensible output in its development In S. Gass \& C. Madden (Eds.), Input in second language acquisition (pp. 235-253). Rowley, MA: Newbury House.

Swain, M. (1988). Manipulating and complementing content teaching to maximize second language learning. TESL Canada Journal, 6, 68-83.

Swain, M. (1996). Integrating language and content in immersion classrooms: Research perspectives. The Canadian Modern Language Review, 52, 529-548.

Swain, M., \& Lapkin, S. (1982). Evaluating bilingual education in Ontario: A Canadian case study. Clevedon: Multilingual Matters.

Swain, M., \& Lapkin, S. (2002). Talking it through: Two French immersion learners' response to reformulation. International Journal of Educational Research, 37, 285-304.

Swain, M., \& Lapkin, S. (2005). The evolving sociopolitical context of immersion education in Canada: Some implications for program development. International Journal of Applied Linguistics, 15, 169-186.

Turnbull, M., Lapkin, S., \& Hart, D. (2001). Grade 3 immersion students' performance in literacy and mathematics: Province-wide results from Ontario (1989-99). The Canadian Modern Language Review, 58, 9-26.

White, J., Horst, M., \& Bell, P. (2008, June). Cross-linguistic awareness: Teachable and effective? Paper presented at the Conference for Language Awareness, Hong Kong.

\section{Appendix 1. Debriefing interview protocol}

(1) Overall, how did you enjoy the experience of reading these three books 'bilingually' to your students? Were there any challenges?

(2) How did you think the students enjoyed it? Was there one of the three books that you feel the children liked more or less than the others? Which one(s) and why?

(3) How do you think the students benefitted from the experience? Do you think some students benefitted more than others? Who, how, and why?

(4) Because of the nature of the shared reading in the other language, do you think you approached the reading differently from how you would normally have done? If so, how? Were there any changes in how you approached the reading of the books as the project progressed?

(5) Did reading these three books to your students influence the curriculum you used? If so, did you find that this was a useful influence? Why or why not?

(6) How did you and teacher $\mathrm{X}$ co-ordinate the readings and any activities related to the book that were done?

(7) Did participating in this project give you any insights into your students' abilities/needs in their two languages? Did it influence the attention you gave to students' language learning needs?

(8) Did you ever have the impression that it might be a challenge for the children to be learning two new words for a new concept at the same time (monk/moine, weaver/tisserand, silk worm/vers à soie, etc.)?

(9) Who do you think tends to benefit more from the French immersion programme: Englishdominant or French-dominant students? Why?

(10) Do you think that it's helpful to encourage students to draw on knowledge of their L1 in order to learn their second?

(11) In order for you to help students use their L1 to learn their second, how extensive do you think your knowledge of their L1 needs to be?

(12) If you were to read another book in the Magic Tree House series, how would you prefer to do it?

- The same way (alternating chapters and languages)

- Read it in English or French only 
- Read the whole book in one language, and read it a second time in the students' other language (read by the other teacher)

(13) What advice would you give to a pair of teachers who wanted to embark on a bilingual reading experience together?

\section{Appendix 2. Student questionnaire}

\section{(Administered in French)}

(1) Circle the answer that best says what you thought of each book.

Panique à Pompéi/Vacation under the Volcano

I liked this book:
(a) a lot
(b) a bit
(c) not at all

I preferred being read to in:
(a) French
(b) English
(c) French and English

Le terrible empereur de Chine/Day of the Dragon King I liked this book:
(a) a lot
(b) a bit
(c) not at all

I preferred being read to in:
(a) French
(b) English
(c) French and English

\section{L'attaque des Vikings/Viking Ships at Sunrise} I liked this book:
(a) a lot
(b) a bit
(c) not at all

I preferred being read to in:
(a) French
(b) English
(c) French and English

(2) Write the titles of other books in the Magic Tree House series that you've read

(3) If the teacher reads another book from the Magic Tree House series to you, what would you like best?
(a) Hear one chapter in French then the next one in English (like the last time)
(b) Hear the whole book in French only
(c) Hear the whole book in English only
(d) Hear the whole book in French first then in English
(e) Hear the whole book in English first then in French 
4. Circle the language (or languages) you speak.

$\begin{array}{llll}\text { With your mother } \Rightarrow & \text { English } & \text { French } & \text { another language } \\ \text { With your father } \Rightarrow & \text { English } & \text { French } & \text { another language } \\ \text { With your brothers/sisters } \Rightarrow & \text { English } & \text { French } & \text { another language } \\ \text { With your friends } \Rightarrow & \text { English } & \text { French another language }\end{array}$

5. Circle the language (or languages) that you feel most comfortable in.

$$
\text { English French another language }
$$

